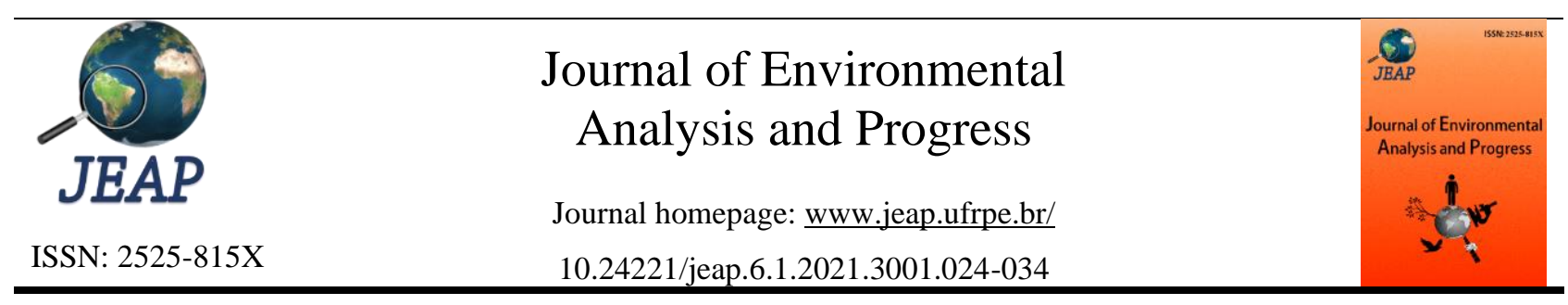

\title{
Vegetation height estimation using satellite remote sensing in peat land of Central Kalimantan
}

\author{
Atriyon Julzarika $^{\mathrm{ab}}$, Harintaka Harintaka ${ }^{\mathrm{a}}$, Tatik Kartika ${ }^{\mathrm{b}}$ \\ a Universitas Gadjah Mada-UGM, Department of Geodesy Geomatics Engineering, Jl. Grafika No. 2 Yogyakarta, \\ Indonesia. E-mail:verbhakov@yahoo.com, harintaka@ugm.ac.id. \\ ${ }^{\mathrm{b}}$ Indonesian National Institute of Aeronautics and Space-LAPAN, Remote Sensing Applications Center, Jl. Kalisari No. \\ 8, Pekayon, Pasar Rebo, Jakarta, Indonesia. E-mail: tatik.kartika@lapan.go.id.
}

\begin{tabular}{|c|c|}
\hline A R T I C L E I N F O & A B S T RA C T \\
\hline $\begin{array}{l}\text { Received } 28 \text { Nov } 2019 \\
\text { Accepted } 26 \text { Jan } 2021 \\
\text { Published } 28 \text { Jan } 2021\end{array}$ & $\begin{array}{l}\text { Vegetation height is an important parameter in monitoring peatlands. Vegetation height } \\
\text { can be estimated using remote sensing. Vegetation height can be estimated by utilizing } \\
\text { DSM and DTM. The data that can be used are LiDAR, X-SAR, and SRTM C. In this } \\
\text { study, LiDAR data is used for DSM2018 and DTM2018 extraction. This research aims } \\
\text { to detect the vegetation height in Central Kalimantan peatlands using remote sensing } \\
\text { technology. The research location is in Bakengbongkei, Kalampangan, Central } \\
\text { Kalimantan. The integration of X-SAR and SRTM C is used for DSM2000 and } \\
\text { DTM2000 extraction. DSM2000, DTM2000, DSM2018, and DTM } 2018 \text { performed } \\
\text { height error correction with tolerance of } 1.96 \sigma \text { (95\%). Then do the geoid undulation } \\
\text { correction to EGM2008. The results obtained are DSM and DTM with a similar height } \\
\text { reference field. If it meets these conditions, it can be calculated the vegetation height } \\
\text { estimation. Vegetation height can be obtained using the Differential DEM method. The } \\
\text { Changing in vegetation height from } 2000 \text { to } 2018 \text { can be estimated from the difference } \\
\text { in vegetation height from } 2000 \text { to vegetation height in } 2018 \text {. Results of spatial } \\
\text { information on vegetation height and its changes need to be tested for accuracy. This } \\
\text { accuracy-test includes a cross-section test, height difference test, and comparison with } \\
\text { vegetation height measurements in the ground. The results of this research can be used } \\
\text { to monitor the changing vegetation height in peatlands. } \\
\text { Keywords: Vegetation height, LiDAR, SAR, Central Kalimantan. }\end{array}$ \\
\hline
\end{tabular}

\section{Introduction}

Vegetation in ecology is a term for the whole plant community in a particular place, including the communal mix of the flora types that make it up and the land cover that it forms. Vegetation is a part of life composed of plants that occupy an ecosystem or ecological niches in a narrower area (Hyde et al., 2006). Different types of forests, gardens, grasslands, and tundra are examples of vegetation (Poggio et al., 2013).

Peatlands are landscapes composed of imperfect decomposition of vegetation from waterlogged trees so that the conditions are anaerobic (KGS, 2016; FAO, 2009). The organic material continues to accumulate for a long time to form layers with a thickness of more than $50 \mathrm{~cm}$ (Hoscilo et al., 2011). There is the potential for mineral and coal energy (Houghton et al., 2012). Coal is a non-renewable energy resource. Based on the level of its formation process, which is controlled by pressure, heat, and time, coal is generally divided into five classes: anthracite, bituminous, sub-bituminous, lignite, and peat (KGS, 2016).

Anthracite is the highest grade of coal, with a metallic luster black, containing between $86 \%$ $98 \%$ carbon element $(\mathrm{C})$ with less than $8 \%$ (Page et al., 2011). Bituminous contains $68-86 \%$ of the element carbon (C) and the water content of $8-10 \%$ by weight - the most widely mined coal class in Australia. Sub-bituminous contains little carbon and lots of water and is, therefore, a less efficient heat source than bituminous. Lignite or brown coal is very soft coal, which contains $35-75 \%$ of its weight. Peat has porous characteristics and has a moisture content above $75 \%$ and the lowest calorific value (Posa et al., 2011). Figure 1 is the coalition on peatlands. 


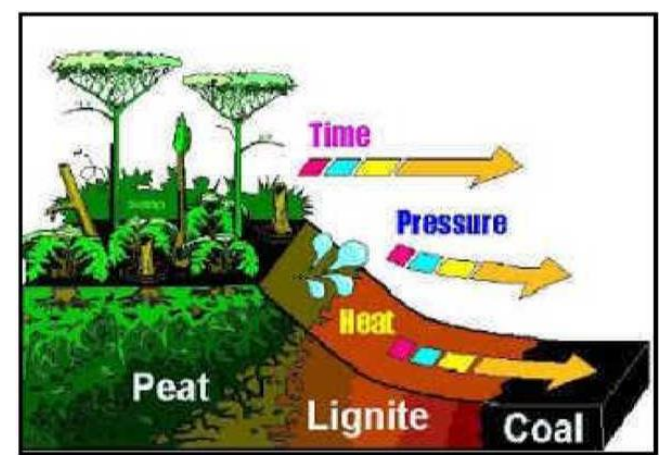

Figure 1. Coalition on peatlands. Font: KGS (2016).

Peat is an early form of coal or rotten plants' accumulation (Konecny et al., 2015). Peat $\left(\mathrm{C}_{60} \mathrm{H}_{6} \mathrm{O}_{34}\right)$ has a brown color, and the material has not been compacted (Reddington et al., 2014). Peat has very high-water content and has shallow reliable carbon content (Singh, 2008). It has a very high-flying carbon content and is very easily oxidized. The value of the heat produced is deficient (KGS, 2016). Peat is useful as an industrial fuel. Lignite or brown coal is the lowest coal rank and is used almost exclusively as fuel for power plants. The lignite form is compact and has been used as an ornamental stone since Upper Palaeolithic times. Lignite (brown coal), $\left(\mathrm{C}_{70} \mathrm{OH}_{5} \mathrm{O}_{25}\right)$ has a brownish color, a compounded material but is very fragile, has high water content, has a low reliable carbon content, has a high-flying carbon content, is easily oxidized, and the value of heat produced is low (KGS, 2016).

One important thing that needs to be done on peatlands is modeling vegetation height prediction (Petrou et al., 2012). Vegetation height plays a vital role in various ecological and environmental applications, such as biodiversity assessment and monitoring, landscape characterization, conservation planning, and disaster management (Brenner et al., 2019). Canopy structure estimation and vegetation height are fundamental to a series of ecological studies (Dong \& Wu, 2008). It includes biodiversity monitoring, conservation planning, fire modeling, and biomass estimation (Simard et al., 2011).

Traditional ground measurements of vegetation height based on the forest's nature are carried out using handheld equipment (Bae et al., 2014). This measurement is expensive, subjective, time-consuming, labor-intensive, and difficult to do, especially in dense forests (Buckley et al., 1999). For this reason, other methods for estimating forest properties over a wider area are often used, such as remote sensing.

Space Geodesy, like remote sensing, involves collecting spatially organized data and information about an area of interest by detecting and measuring signals (Popescu \& Wynne, 2004). It is composed of radiation, particles, and fields emanating from objects located beyond the sensor devices (Franklin, 2001). In this way, it offers the potential for more efficient resource assessment. The data are in the form of optical images, Synthetic Aperture Radar, sonar, video, and Light Detection and Ranging (LiDAR).

Optical images can be Landsat, PlanetScope, WorldView, and others. SAR image in the form of X SAR, SRTM, ALOS PALSAR, Sentinel 1, or similar. LiDAR technology provides detailed measurements of different forest properties because of its next generation of 3D data, its accuracy, and its acquisition flexibility (Hyyppä et al., 2000). However, existing LiDAR sensors have limited spatial coverage and a relatively high acquisition cost (Ruiz et al., 2014). On the other hand, satellite data are low-cost and offer broader spatial coverage of generalized forest structure but are not expected to provide accurate vegetation height information. The integration of LiDAR and satellite data promises to improve the measurement, mapping, and monitoring of forest properties (Popescu \& Wynne, 2004; Bergen et al., 2009).

One of the most critical forest properties is vegetation height and canopy cover (Seavy et al., 2009). Vegetation height is the height of the vegetation in a stand, relative to the ground. It is a function of the species composition, climate, and site quality and can be used for land-cover classification or in conjunction with vegetation indices (Poggio \& Gimona, 2014). If coupled with species composition and site quality information, vegetation height serves as an estimate of the stand age or the successional stages (Zhou et al., 2009). Vegetation height is also a useful indicator of forest age and habitat quality. It is an essential input variable for ecosystem and forest fire models and is positively correlated with vegetation biomass and productivity (Carlson et al., 2012).

Space Geodesy in vegetation height estimation when in situ or LiDAR data are not available or affordable, thus facilitating and reducing the cost of ecological monitoring and environmental sustainability planning tasks. This condition shows a promising alternative in estimating vegetation height when in situ or LiDAR data is not available or affordable, thus facilitating and reducing the costs of ecological monitoring and environmental sustainability planning tasks.

Vegetation height is also an indicator of forest age and valuable habitat quality (Flynn et al., 2002). It is an essential input variable for ecosystem models and forest fires and is positively 
correlated with vegetation biomass and forest modeling because it uses accurate 3D data and flexibility in its acquisition (Birdal et al., 2017). The LiDAR sensor complies with this condition. However, LiDAR sensors have limited spatial coverage and relatively high acquisition costs (Hopkinson et al., 2006). Satellite data has the advantage of low cost and offers more extensive spatial coverage. The disadvantage is that it cannot provide direct information related to the vegetation height. The integration of LiDAR and satellite data will help improve the measurement, mapping, and monitoring of forest properties (Trier et al., 2018).

Research from Noggle and Fritz (1983) states that vegetation growth can be seen from increased vegetation height, length, width, leaf area, dry weight of organs (roots, stems, leaves, and fruit), number of cells, and content of specific chemical elements. One method that can be used for height detection of vegetation is from satellite image data with a height model approach (Gehrke et al., 2008).

Height models can be made from optical, radar, and sonar data (Maune \& Nayegandhi, 2018). The height model uses optical satellite image data, aerial photography, video (Kumay 2015). In optical data, height models can be done using the stereo model method, videogrammetry, and perceptive depth cue. In addition to optical data, radar satellite data can also be used to create height models.

Nowadays, the problem faced in determining the relative vegetation height is rapid mapping and large areas. Besides, the available Digital Surface Model (DSM) has not yet been made of height error correction and has not been downgraded to Digital Terrain Model (DTM) (Vanicek \& Krakiwsky, 1986). One way that can be used to correct height errors and DTM is to approach the calculation of leveling (Gillani \& Wolf, 2006). The algorithm is built based on the correlation of surface height with orthometric height in the lowest low grade (Maune \& Nayegandhi, 2018). This algorithm, which is used for determining the relative height of a surface, can be used to calculate vegetation height (Lee et al., 2011). This vegetation is detected by classification (Maune \& Nayegandhi, 2018). This study aimed to detect the vegetation height in Central Kalimantan peatlands with space geodesy technology.

\section{Material and Methods \\ Study area}

The area studied was Bakengbongkei, Kalampangan. This area is located on the border of Pulang Pisau Regency and Palangkaraya City. The Pulang Pisau Regency is a regency in Central Kalimantan province; Palangkaraya City is the capital, with 8,997 km².

Central Kalimantan is a place of national priority Peat Hydrological Unity or Kesatuan Hidrologis Gambut (KHG). This area is peatland with peat depth $>20 \mathrm{~m}$. In this region, there is a lot of peat potential (Van Den Eelaart, 2008). Remote sensing data can be used to explain various physical forms and changes in natural resources. The location of the study can be seen in Figure 2 .

\section{Data collection}

$\mathrm{X}-\mathrm{SAR}$ is a cooperative space project between Germany and Italy in the field of Earth observation from space. SRTM C is a NASA space program that is carried out in conjunction with the X-SAR program. Both sensors use the same SPCA shuttle. X-SAR uses band X, and SRTM uses band C. X-SAR has a spatial resolution of 1 arc-second with a relative vertical accuracy of 3-5 m. SRTM C has a spatial resolution of 3 arc seconds with a relative vertical accuracy of 3-8 $\mathrm{m}$. X-SAR data is integrated with SRTM C (Reuter et al., 2007). This integration of data is used as 2000 data.

LiDAR is an object detection method that uses the principle of laser beam reflection to measure the distance of objects on the earth (García et al., 2018; Maune \& Nayegandhi, 2018). This technology was first used in the 1960s for aviation purposes but has only been famous for mapping systems since the 1980s. The working principle of LiDAR is elementary (Hill \& Broughton, 2009). LiDAR calculates the distance by removing the laser transmitter's light to a surface, then calculating how long it takes the laser beam to return to the receptor (Ackers et al., 2015).

LiDAR devices shoot laser light rapidly at a surface; even some LiDAR devices shoot around 150,000 laser pulses per second. Then the sensor component in LiDAR calculates the time taken from each laser pulse to bounce from a surface to the sensor so that the distance calculation results are obtained with high accuracy (Koma et al., 2019). 

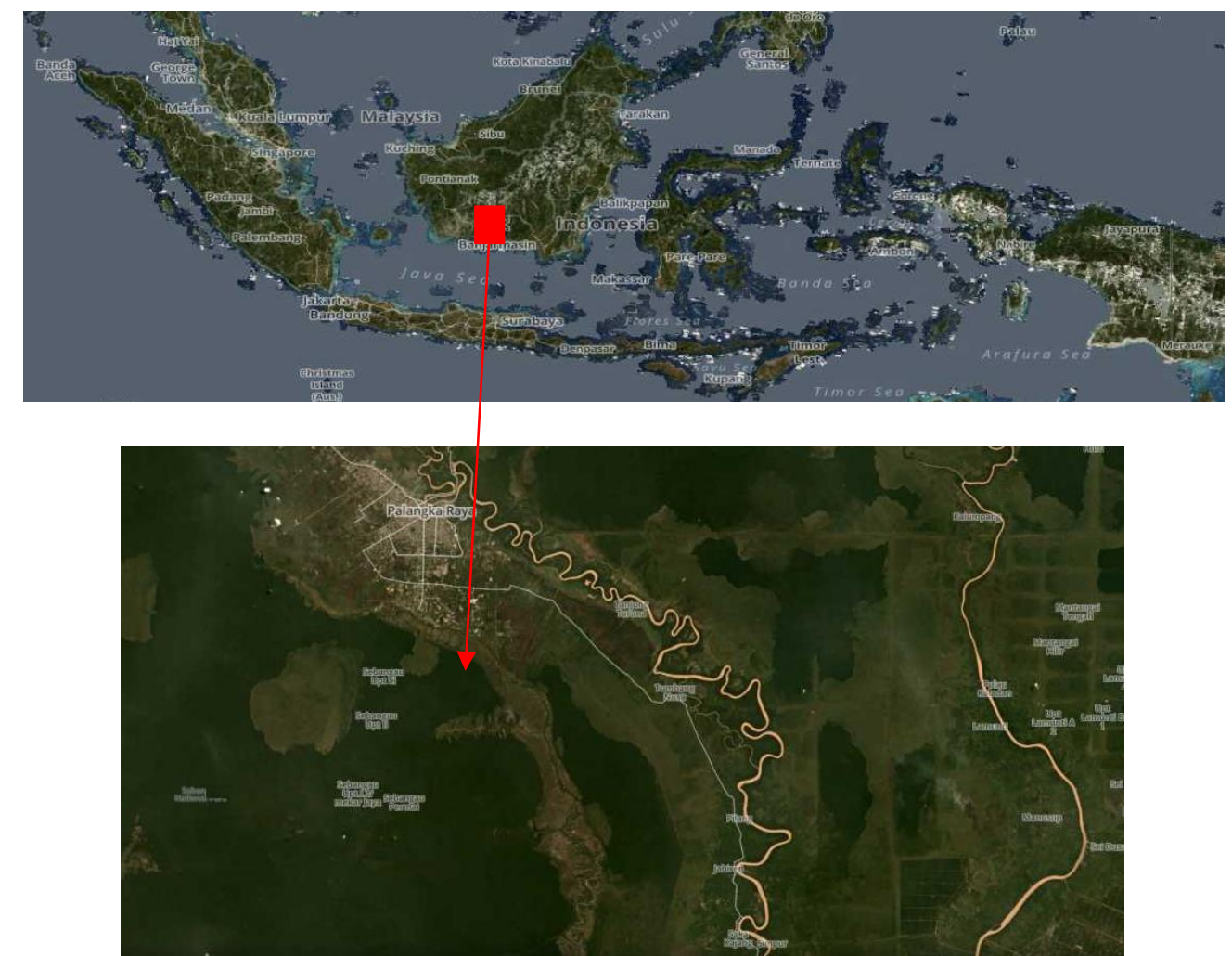

Figure 2. Research location in Bakengbongkei, Central Kalimantan, Indonesia. Font: PlanetScope Imageries in November 2019.

\section{Differential DEM}

DSM is made using the SAR interferometry (InSAR) method (Gehrke et al., 2008; Lee et al., 2011). DSM2000 is a DSM in 2000 that was made in INSAR with X-SAR and SRTM C data. Both of these data were integrated into DEM. It aims to create a new DSM with the advantages of each input data. DSM from X SAR has a high spatial resolution, but the data coverage is not much. SRTM C has the advantage of widearea coverage, and data penetration is closer to the ground compared to X SAR data. Each DSM's advantages are integrated to produce a new DSM (DSM2000) with high spatial resolution and higher vertical accuracy. DTM2000 is obtained from DSM2000 conversion by considering various factors such as the point of view of the treetops, the canopy's width, and others.

DSM2018 is DSM in 2018, which was extracted from recording with LiDAR. LiDAR mapping recorded each point clouds in DSM and DTM conditions. It also needs to be done by choosing the first return point and the last return point. This first return point is then used in making DSM. The last return point is used to make DTM. This DTM was later named DTM2018. The second return point is used in canopy detection. This canopy becomes an indicator in the detection of vegetation.

Every DSM and DTM processing will require height error correction and geoid undulation correction. DSM2000, DTM2000, DSM2018, and DTM2018 performed height error correction with a tolerance of $1.96 \sigma$ (95\%) (ASPRS, 2014). Geoid undulation correction using Earth Gravitational Model (EGM) 2008. After correction, all DSM and DTM used in this study already have a similar height reference field.

The method for calculating vegetation height uses the Differential DEM method. This method reduces height on DSM with DTM. Vegetation height of 2000 was obtained from DSM2000 reduced by DTM2000. Likewise, the vegetation height of 2018 was obtained from the reduction of DSM2018 with DTM2018.

Changes in vegetation height from 2000 to 2018 were obtained because of a reduction in vegetation height in 2018, with a vegetation height of 2000. The height yield of vegetation is then checked for accuracy testing. There are three methods used: the cross-section test, the height difference test, and the comparison test with the height measurement data for vegetation in the ground. 


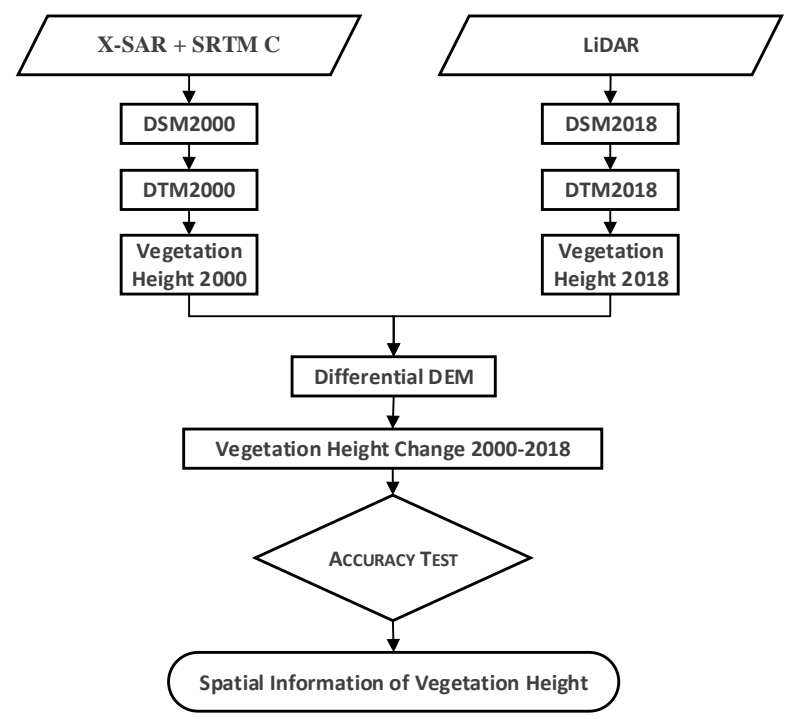

Figure 3. Research flowchart. Font: Julzarika et al. (2020).

The accuracy test also uses a tolerance of $1.96 \sigma(95 \%)$ (ASPRS, 2014). The result of this accuracy test is spatial information about changes in vegetation height. Explanations regarding methods and procedures for obtaining spatial information on vegetation height can be seen in the flow chart in Figure 3.

\section{Results and Discussion}

The results obtained from this study are DSM, DTM, and vegetation height. X SAR produced DSM in 2000 and DTM in 2000, and vegetation height in 2000. LIDAR data produced DSM in 2018, DTM in 2018, and vegetation height in 2018. The difference between the two data in 2000 and 2018 will result in changes in vegetation height.

The DSM 2000 resulted from the integration of DEM X SAR and SRTM C. Both of the DEMs were integrated, and some corrections were made, such as height error correction and geoid undulation correction. The geoid field used is EGM2008. Height errors can be minimized by filtering data with a $95 \%$ confidence level. The maximum DSM value in 2000 is $32 \mathrm{~m}$, and the minimum value is $-12 \mathrm{~m}$. Several regions have negative elevation values. This value is located on the river and swamp. Figure 4 is DSM2000.

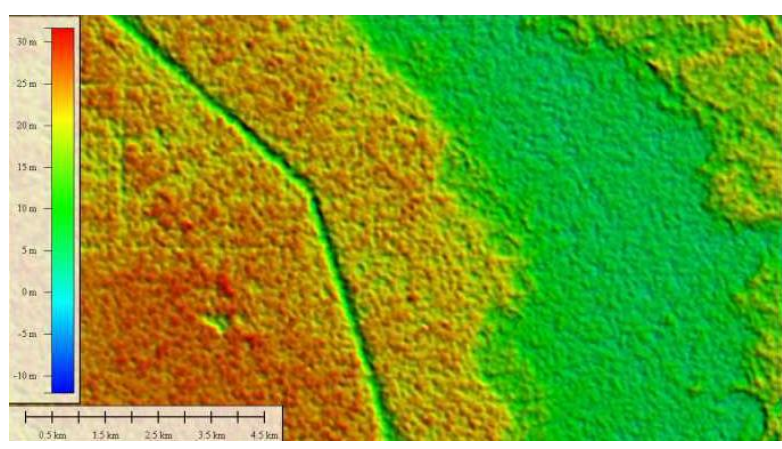

Figure 4. DSM in 2000 (DSM2000) was extracted from the integration of X-SAR and SRTM C. Font: Julzarika et al. (2020).

The DTM2000 was converted from DSM2000 data. The DSM2DEM method is used in the conversion of DSM to DTM. From the results of DTM2000, it is obtained that the maximum elevation value is $9.2 \mathrm{~m}$. Figure 5 is DTM2000.

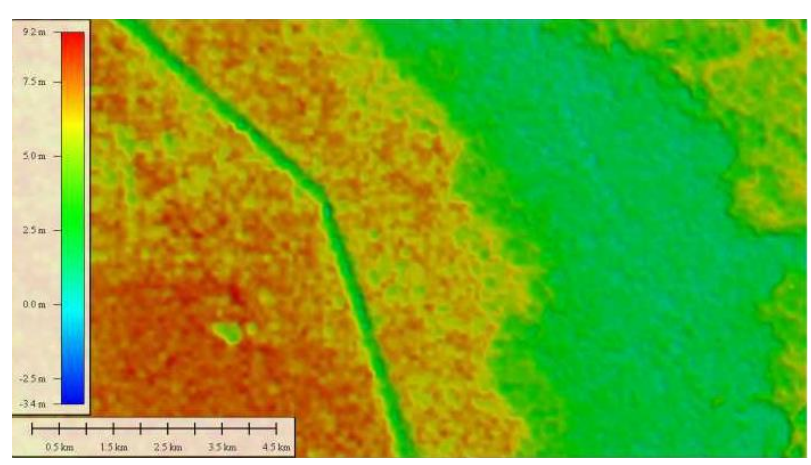

Figure 5. DTM in 2000 (DTM2000), it is converted from DSM2000 to be DTM. Font: Julzarika et al. (2020).

DSM2018 obtained the extraction of LiDAR processing. DSM is extracted using point clouds from the first return. All selected data need to be checked for height errors. Usually, LiDAR recording results of data are minimal height errors occur. Figure 6 is DSM2018.

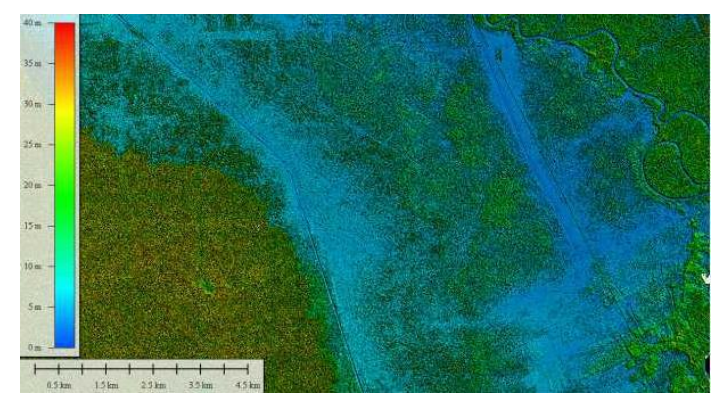

Figure 6. DSM in 2018 (DSM2018) was extracted from LiDAR. Font: Julzarika et al. (2020).

In addition to DSM, data recording LiDAR data can also be used for making DTM. The last return points could data is used for making DTM. The data also needs to be checked for height errors. Elevation in terrain has obtained a maximum of 9.7 
$\mathrm{m}$. There are some lower height points and are in areas that have water. DTM in 2018 (DTM2018) was extracted from the last return points cloud data, see Figure 7.

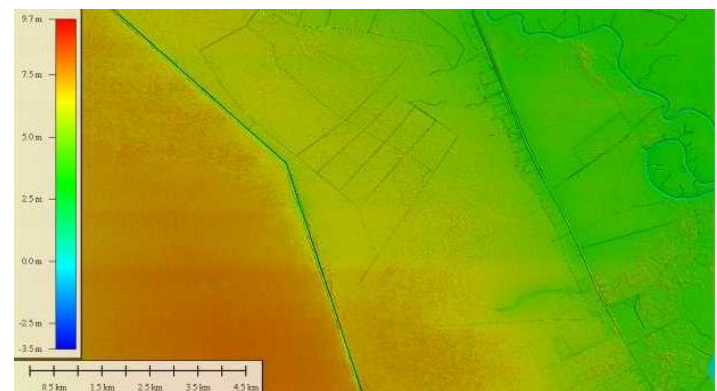

Figure 7. DTM in 2018 (DTM2018). It was extracted from the last return of points cloud data in LiDAR. Font: Julzarika et al. (2020).

At the vegetation height in 2000, the maximum value was $24.5 \mathrm{~m}$, while the minimum value was $-3 \mathrm{~m}$. This area has land cover in the form of primary forests, oil palm plantations, and shrubs. The condition of this land cover, which became this region, has a higher land cover. A river also crosses this region. Figure 8 shows the vegetation height in 2000 .

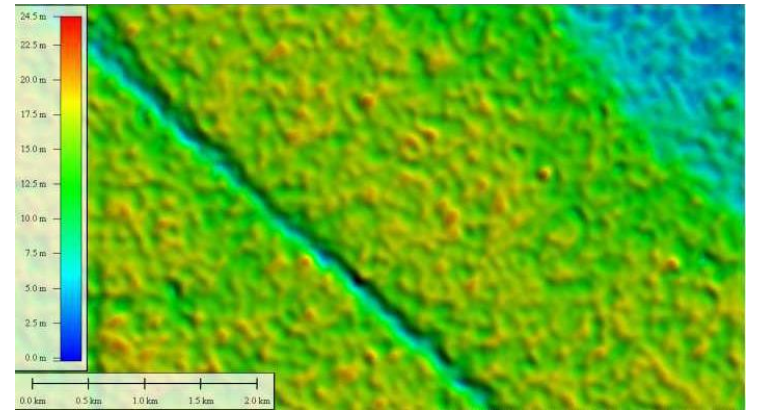

Figure 8. Vegetation height in 2000. Font: Julzarika et al. (2020).

At the vegetation height in 2018, a maximum value of $70 \mathrm{~m}$ is obtained and a minimum value of $43 \mathrm{~m}$. Some vegetations have increased height. The area of oil palm plantations experienced a more significant increase in height. Figure 9 is the height vegetation 2018.

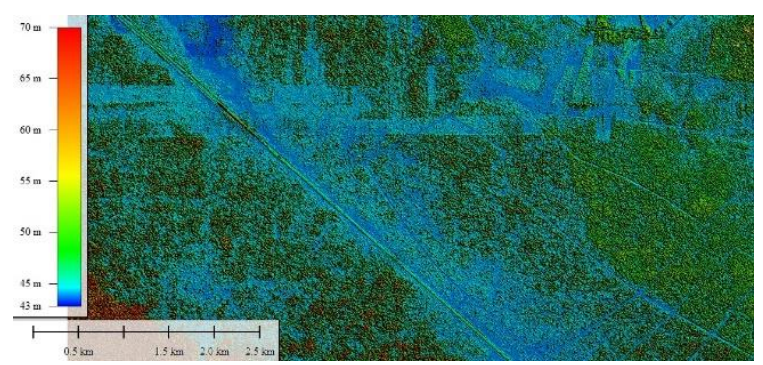

Figure 9. Vegetation height in 2018. Font: Julzarika et al. (2020).
Vegetation height in 2000 and vegetation height in 2018 can be used to estimate changes in vegetation height in 2000-2018. A difference operation carried out the data between the vegetation's height on the same object. The change in vegetation height in this area is $20-45 \mathrm{~m}$. Figure 10 shows the changing of vegetation height in 2000-2018.

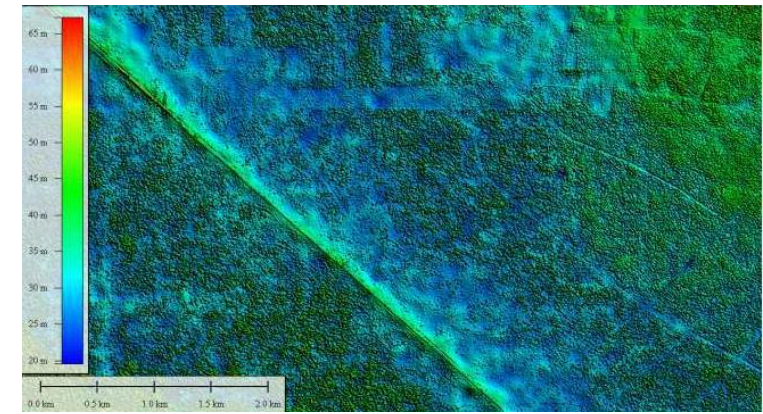

Figure 10. Vegetation height change in 2000-2018. Font: Julzarika et al. (2020).

Accuracy testing is done in three ways: the cross-section test, the height difference test, and comparison with ground measurement data.

\section{Cross-section accuracy test}

The cross-section reflects the region's DTM appearance. This cross-section includes the river-road section. Quantitatively, it can be described as the height difference between the plains around the river and the river thalweg. These differences can be seen in the cross-section between DSM2020-DSM2018 (see Figure 11) and the cross-section between DSM2000-DTM2000 (see Figure 12). It can be seen that the difference in height on the river bank is not extreme, and the topography is flat. It illustrates that the condition of the DTM is approaching the conditions in the ground. In the river area, the height difference is vast, indicating the depth of the river. Cross-section checking between DSM and DSM is also required. It aims to see the appearance of the profile along the line being tested. Figure 11 is a cross-section of DSM2000 and DSM2018.

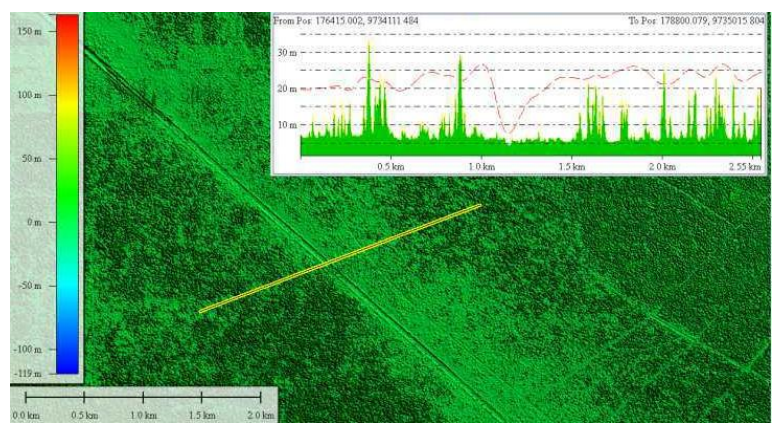

Figure 11. The cross-section between two DSM change in 2000-2018. Font: Julzarika et al. (2020). 
If we look at the cross-section, there are two lines; red and yellow. The red line area is where the vegetation has been cut down, for example, at the starting point of cross-section checking.

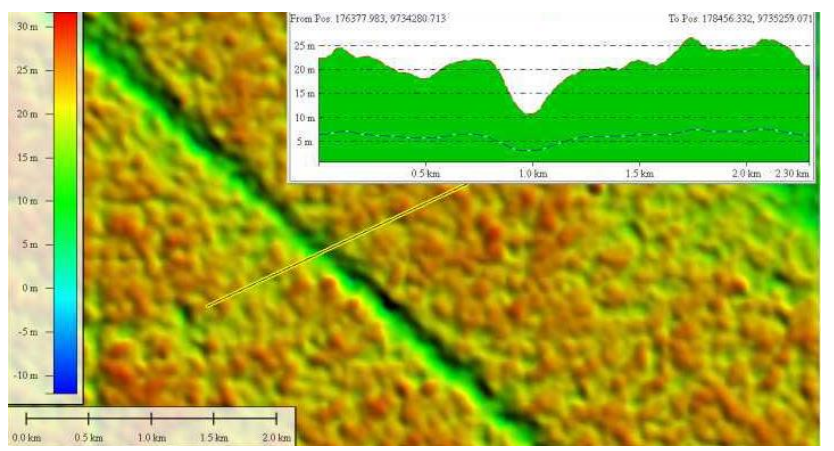

Figure 12. A cross-section between DSM and DTM change in 2000. Font: Julzarika et al. (2020).

Cross-section checking between DSM and DTM is also required. Checking is done on DSM2000 with DTM2000. Figure 12 is a crosssection that crosses a river. For example, at the beginning of the line, the DSM value is located at $22 \mathrm{~m}$ elevation while the DTM value is $6 \mathrm{~m}$. Based on these conditions, the vegetation height value is
$16 \mathrm{~m}$, likewise with other objects. Visually, the surface pattern and the DSM2000 and DTM2000 terrain patterns are still in the normal range. The cross-section also shows that river patterns and shapes are still suitable for the DSM and DTM.

\section{Height difference test}

The height difference test can be useful in determining the height difference between two or more points. The height difference between the point's determination refers to the average sea level, local height, or ellipsoid, while the whole point on the height model refers to a specific reference plane or datum. If all points tested in closed polygon form have a minimum height difference value (close to zero), the height model has a point height relative to the data. It eliminated the systematic errors that still exist in the height model. Height difference test results on DTM of 1.753e-16 $(\sim 0)$. It indicates that DTM integration is free of blunders, systematic errors, and minimal random errors.

\section{Comparison test with ground measurements}

There are three test locations conducted in this region. These locations can be seen in Table 1 .

Table 1. Comparison of the height difference of vegetation height (processed) with vegetation height (ground). Vegetation height (processed) was extracted from DSM and DTM processing. Vegetation height (ground) is from ground survey measurement. Font: Julzarika et al. (2020).

\begin{tabular}{cccccc}
\hline $\mathbf{N}^{\circ}$ & Latitude & Longitude & $\begin{array}{c}\text { Vegetation height } \\
\text { (processed) }\end{array}$ & $\begin{array}{c}\text { Vegetation height } \\
\text { (ground) }\end{array}$ & $\begin{array}{c}\text { Height } \\
\text { difference }\end{array}$ \\
\hline 1 & $2^{\circ} 22^{\prime} 25.8798^{\prime \prime} \mathrm{S}$ & $114^{\circ} 06^{\prime} 17.8010^{\prime \prime} \mathrm{E}$ & $5.107 \mathrm{~m}$ & $5.3 \mathrm{~m}$ & $0.193 \mathrm{~m}$ \\
2 & $2^{\circ} 20^{\prime} 59.8805^{\prime \prime} \mathrm{S}$ & $114^{\circ} 05^{\prime} 32.6671^{\prime \prime} \mathrm{E}$ & $7.533 \mathrm{~m}$ & $7.7 \mathrm{~m}$ & $0.167 \mathrm{~m}$ \\
3 & $2^{\circ} 19^{\prime} 59.6768^{\prime \prime} \mathrm{S}$ & $14^{\circ} 04^{\prime} 26.9091^{\prime \prime} \mathrm{E}$ & $4.588 \mathrm{~m}$ & $4.8 \mathrm{~m}$ & $0.212 \mathrm{~m}$ \\
\hline
\end{tabular}

Tests at point 1 were made to compare the vegetation height (processed) with the vegetation height measured in the ground. Vegetation height (processed) is $5.107 \mathrm{~m}$, while vegetation height (ground) is $5.3 \mathrm{~m}$. The difference in height between the two measurements was $0.193 \mathrm{~m}$. Measurement at point 2 obtained a vegetation height (processed) of $7.533 \mathrm{~m}$ while vegetation height (ground) of 7.7 $\mathrm{m}$, meaning a difference in a height difference of $0,167 \mathrm{~m}$. Point 3 has a vegetation height (processed) of $4.588 \mathrm{~m}$, while the results of measurements in the ground obtained a vegetation height of $4.8 \mathrm{~m}$, meaning a difference in a height difference of $0.212 \mathrm{~m}$.

Vegetation height estimation can be extracted from DSM and DTM of remote sensing data (Rybansky et al., 2016). It can be predicted by comparing DSM with DTM (Rybansky et al., 2016). Vegetation height change can be obtained by the difference in vegetation height in 2000, with vegetation height in 2018. Vegetation height in
2018 can be tested by measuring the vegetation height in the ground. Vegetation height can be estimated from texture analysis (Petrou et al., 2012). This height difference is needed to determine the quality of the resulting height data. This quality is known for vertical accuracy by comparing it with field measurements (Petrou et al., 2012). The vertical accuracy shows the maximum error allowed in vegetation height mapping. (Hopkinson et al., 2004). This error can occur due to land cover in grass/shrub areas and water vegetation cover in peat swamps. Errors that occur can be minimized with high data with high vertical accuracy (Hopkinson et al., 2004).

The vertical accuracy test is carried out by comparing the measurement height with the results of field measurements. From the height difference in Table 1, we can see that the value is $<0.5 \mathrm{~m}$. It indicates that the vegetation height obtained from DSM and DTM is more optimal to visualize. It can 
be used for vegetation height mapping for a wider area with relatively sufficient time and low cost.

From Table 1, the DTM difference test indicates that DTM is free of blunders, systematic errors, and minimal random errors. From the crosssection, we can see the DSM in 2000 has an elevation of $20 \mathrm{~m}$ while in DSM in 2018, the elevation is around $2 \mathrm{~m}$. It indicates a reduction in vegetation height. This condition generally occurs in areas with land cover in the form of oil-palm plantations and industrial plantations. The vegetation height estimation results can be used for various survey mapping applications.

The effect of errors on the DTM difference test in Table 1 was also found in other studies regarding the accuracy in estimating vegetation height (Stereńczak \& Zasada, 2011). Their research is related to checking the accuracy of tree height estimates with LiDAR data in temperate rain forests. The algorithm they use is that segmenting stands into individual trees (Stereńczak. et al., 2008). They found the cause of the error that caused the vegetation height estimate to be less than optimal. In this study, the causes of height estimation errors were also taken into account to get an accurate vegetation height value. These errors are in the form of errors in estimating the treetop height, the model ground height, and the tree slope, and the relationship between these errors and the stand level and location variables is explored (Naesset \& Bjerknes, 2001; Järnstedt et al., 2012).

The measurement of vegetation height estimates the results from the reduction of DSM with DTM (Anggraini \& Julzarika, 2019). The vegetation height is relative, which illustrates the dominant condition on each DTM pixel. The DTM is the result of conversion from DSM. The vegetation height can also be used for surface volume calculations (Garcia et al., 2018).

In the DTM, the vertical accuracy value is $60.4 \mathrm{~cm}$, and the DTM can be used for 1: 10000 scale mapping. The DSM obtained a vertical accuracy-test value of $37 \mathrm{~cm}$ and can be used for mapping a scale of 1:10,000. In this study, the high difference value was also obtained $<0.5 \mathrm{~m}$. This condition is similar even though it is different in the study area and can be used for mapping at a scale of 1: 10,000 .

Research on vegetation height with LiDAR data and QuickBird imagery has been carried out (Su et al., 2012). They do this by segmenting the QiuckBird image and filtering LiDAR based on mathematical morphology to obtain tree boundaries. The highest point on each object is used to estimate tree height. (Persson \& Perko,
2016). The highest point is the DSM, while the lowest point is the DTM used in this study.

\section{Conclusion}

Remote sensing data can be used for vegetation height estimation. Vegetation height in 2000 is calculated from DSM and DTM resulting from the integration of X-SAR and SRTM C. Vegetation height in 2018 can be calculated from DSM and DTM LiDAR. The difference in vegetation height of 2000-2018 can be estimated from the vegetation height of 2000 and vegetation height of 2018. DSM, DTM, and vegetation height were tested for accuracy in three ways, namely the cross-section test, height difference test, and comparison with ground measurements.

\section{Acknowledgments}

The authors thank LAPAN, UGM, Planet.com, Mr. Yudi Lasmana from the Research center for the swamp in the Ministry of Public Work and Housing, Mr. Noor Jamaluddin from BPBD of South Kalimantan for supporting this research project.

\section{References}

Ackers, S. H.; Davis, R. J.; Olsen, K. A.; Dugger, K. M. 2015. The evolution of mapping habitat for northern spotted owls (Strix occidentalis caurina): A comparison of photo-interpreted, Landsat-based, and LiDAR-based habitat maps. Remote Sensing of Environment, 156, 361-373. DOI: 10.1016/j.rse.2014.09.025

Anggraini, N.; Julzarika, A. 2019. Detection of Vegetation Height in Mahakam Delta Using Remote Sensing. Journal OLDI, 4, 3, 175186. DOI: $10.14203 /$ oldi.2019.v4i3.212

ASPRS. 2014. ASPRS Accuracy Standard for Digital Geospatial Data. The American Society for Photogrammetry and Remote Sensing, ASPRS, United States of America.

Bae, S.; Reineking, B.; Ewald, M.; Mueller, J. 2014. Comparison of airborne LiDAR, aerial photography, and field surveys to model the habitat suitability of a cryptic forest species The hazel grouse. International Journal of Remote Sensing, 35, 6469-6489. DOI: 10.1080/01431161.2014.955145

Bergen, K. M.; Goetz, S. J.; Dubayah, R. O.; Henebry, G. M.; Hunsaker, C. T.; Imhoff, M. L.; ... Radeloff, V. C. 2009. Remote sensing of vegetation 3-D structure for biodiversity and habitat: Review and implications for LiDAR and radar spaceborne missions. Journal of Geophysical Research: Biogeosciences, 114, G00E06. DOI: 10.1029/2008JG000883 
Birdal, A.C.; Avdan, U.; Türk, T. 2017. Estimating tree heights with images from an unmanned aerial vehicle. Geomatics Nat. Hazards Risk, 2017, $\quad 8, \quad 1144-1156, \quad$ DOI: 10.1080/19475705.2017.1300608.

Brenner, A.; Zwally, H.; Bentley, C.; Csatho B.; Harding, D.; Hofton, M.; Minster, J.; Roberts, L.; Saba, J.; Thomas, J. 2019. Geoscience Laser Altimeter System (GLAS) - derivation of range and range distributions from laser pulse waveform analysis for surface elevations, roughness, slope, and vegetation heights. Algorithm Theoretical.

Buckley, D. S.; Isebrands, J.; Sharik, T. L. 1999. Practical field methods of estimating canopy cover, PAR, and LAI in Michigan Oak and pine stands. North. J. Appl. For., 16, (1), 25 32.

Carlson, K. M.; Curran, L. M.; Asner, G. P.; Pittman, A. M.; Trigg, S. N.; Adeney, J. M. 2012. Carbon emissions from forest conversion by Kalimantan oil palm plantations. Nature Climate Change, 3, 283288.

Dong, L.; Wu, B. 2008. A comparison of estimating forest canopy height integrating multi-sensor data synergy - A case study in the mountain area of Three Gorges. The International Archives of the Photogrammetry, Remote Sensing and Spatial Information Sciences, ISPRS, Beijing, XXXVII, Part B1, 384-379. Beijing.

Flynn, T.; Tabb, M.; Carande, R. 2002. Coherence region shape extraction for vegetation parameter estimation in polarimetric SAR interferometry. IEEE International Geoscience and Remote Sensing Symposium. pp. 2596-2598. DOI: 10.1109/IGARSS.2002.1026712.

FAO. 2009. FAO/IIASA/ISRIC/ISSCAS/JRC, harmonized world soil database (version 1.1). FAO, Rome, Italy, and IIASA, Luxemburg, Austria. Food and Agriculture Organization, FAO, Rome.

Franklin, S. E. 2001. Remote sensing for sustainable forest management. CRC Press. 1st Edition. ISBN 9781566703949. DOI: 10.1201/9781420032857.

García, M.; Saatchi, S.; Ustin, S.; Balzter, H. 2018. Modeling forest canopy height by integrating airborne LiDAR samples with satellite Radar and multispectral imagery. Int. J. Appl. Earth Obs. Geoinf., 66, 159-173.

Gehrke, S.; Morin, K.; Downey, M.; Boehrer, N.; Fuchs, T. 2008. Semi-global matching: An alternative to LiDAR for DSM generation?
Int. Arch. Photogram. Remote Sens. Spat. Inf. Sci., XXXVIII-B1, 1-6.

Gillani, C.; Wolf, P. R. 2006. Adjustment computation: spatial data analysis. John Wiley \& Sons, Inc., Hoboken, New Jersey. The United States of America.

Hill, R. A. L.; Broughton, R. K. 2009. Mapping the understorey of deciduous woodland from leaf-on and leaf-off airborne LiDAR data: A case study in lowland Britain. ISPRS Journal of Photogrammetry and Remote Sensing, 64, 223-233. DOI: $\quad 10.1016 / j$. isprsjprs.2008.12.004.

Hopkinson, C.; Chasmer, L. E; Zsigovics, G.; Creed, I. F.; Sitar, M.; Treitz, P.; Maher; R. V. 2004. Errors in LiDAR ground elevation and wetland vegetation height estimates. International Archives of Photogrammetry, Remote Sensing and Spatial Information Sciences, XXXVI, 8/W2.

Hopkinson, C.; Chasmer, L.; Lim, K.; Treitz, P.; Creed, I. 2006. Towards a universal LiDAR canopy height indicator. Canadian Journal of Remote Sensing, 32, (2), 139-152.

Hoscilo, A.; Page, S. E.; Tansey, K. J.; Rieley, J. O. 2011. Effect of repeated fires on landcover change on peatland in southern Central Kalimantan, Indonesia, from 1973 to 2005. International Journal Wildland Fire, 20, 4, 578-588.

Houghton, R. A.; House, J. I.; Pongratz, J.; van der Werf, G. R.; Defries, R. S.; Hansen, M. C. 2012. Carbon emissions from land-use and land-cover change. Biogeosciences, 9, 51255142.

Hyde, P.; Dubayah, R.; Walker, W.; Blair, J. B.; Hofton, M.; Hunsaker, C. 2006. Mapping forest structure for wildlife habitat analysis using multi-sensor (LiDAR, SAR/InSAR, ETM+, QuickBird) synergy. Remote Sens. Environ., 102, (1-2), 63-73.

Hyyppä, J.; Hyyppä, H.; Inkinen, M.; Engdahl, M.; Linko, S.; Zhu, Y. H. 2000. Accuracy comparison of various remote sensing data sources in the retrieval of forest stand attributes. Forest Ecology and Management, 128, 109-120.

Järnstedt, J.; Pekkarinen, A.; Tuominen, S.; Ginzler, C.; Holopainen, M.; Viitala, R. 2012. Forest variable estimation using a highresolution digital surface model.ISPRS J. Photogramm. Remote Sens., 74, 78-84.

KGS. 2016. Coal information. Kentucky Geological Survey, KGS, University of Kentucky.

Koma, Z.; Seijmonsbergen, A. C.; Kissling, W. D. 2019. Use and categorization of Light 
Detection and Ranging vegetation metrics in avian diversity and species distribution research. Divers Distrib., 25, 1045-1059. DOI: 10.1111/ddi.12915.

Konecny, K.; Ballhorn, U.; Navratil, P.; Jubanski, J.; Page, S. E.; Tansey, K. 2015. Variable carbon losses from recurrent fires in drained tropical peatlands. Glob Change Biol., 22, 4, 1469-1480.

Kumay, D. U. 2015. Remote sensing platforms and sensor. NBKRIST Vidyanagar. India.

Lee, S.; Kugler, F.; Papathanassiou, K.; Hajnsek, I. 2011. Multibaseline polarimetric sar interferometry forest height inversion approaches. PolINSAR2011. ISBN: 978-929092-259-9.

Maune. D. F.; Nayegandhi, A. 2018. Digital Elevation Model-DEM users manual. Digital Elevation Model technologies and applications. 3rd Edition. ASPRS.

Naesset E.; Bjerknes K. 2001. Estimating tree heights and number of stems in young forest stands using airborne laser scanner data. Remote Sensing of Environment, 78, 328340.

Noggle, G. R.; Fritz, J. F. 1983. Introductory plant physiology. 2nd Edition, Prentice Hall Inc., Englewood Cliffs, pp. 440-442.

Page, S. E.; Rieley, J. O.; Banks, C. J. 2011. Global and regional importance of the tropical peatland carbon pool. Global Change Biology, 17, 2, 798-818. DOI: 10.1111/j.1365-2486.2010.02279.x

Persson, H. J.; Perko, R. 2016. Assessment of boreal forest height from WorldView-2 satellite stereo images.Remote Sens. Lett., 7, 1150-1159.

Petrou, Z.; Tarantino, C.; Adamo, M.; Blonda, P.; Petrou, M. 2012. Estimation of vegetation height through satellite image texture analysis. ISPRS - International Archives of the Photogrammetry, Remote Sensing and Spatial Information Sciences. XXXIX-B8. XXII ISPRS Congress, 25 August 01 September 2012, Melbourne, Australia. DOI: 10.5194/isprsarchives-XXXIX-B8-3212012.

Poggio, L.; Gimona, A. 2014. National scale 3D modelling of soil organic carbon stocks with uncertainty propagation-An example from Scotland. Geoderma, 232-234, 284-299.

Poggio, L.; Gimona, A.; Brewer, M. J. 2013. Regional scale mapping of soil properties and their uncertainty with a large number of satellite-derived covariates. Geoderma, 209210, 1-14.
Popescu, S. C.; Wynne, R. H. 2004. Seeing the trees in the forest: Using LiDAR and multispectral data fusion with local filtering and variable window size for estimating tree height. Photogram. Eng. Remote Sens., 70, 589-604. DOI:10.14358/PERS.70.5.589.

Posa, M. R. C.; Wijedasa, L. S.; Corlett, R. T. 2011. Biodiversity and conservation of tropical peat swamp forests. BioScience, 61, (1), 49-57. DOI: 10.1525/bio.2011.61.1.10.

Reddington, $\quad$ C. $\quad$ L.; Yoshioka, M.; Balasubramanian, R.; Ridley, D.; Toh, Y. Y.; Arnold, S. R. 2014. Contribution of vegetation and peat fires to particulate air pollution in Southeast Asia. Environ Res Lett., 9, 9, 094006 (12 p).

Reuter, H. I.; Nelson, A.; Jarvis, A. 2007. An evaluation of void-filling interpolation methods for SRTM data. Int. J. Geogr. Inf. Sci., 21, 983-1008.

Ruiz, L.; Hermosilla, T.; Mauro, F.; Godino, M. 2014. Analysis of the influence of plot size and LiDAR density on forest structure attribute estimates. Forests, 5, 936-951. DOI: 10.3390/f5050936.

Rybansky, M.; Brenova, M.; Cermak, J.; van Genderen, J.; Sivertun, A. 2016. Vegetation structure determination using LIDAR data and the forest growth parameters. IOP Conf. Series: Earth and Environmental Science, 37, $012031 \quad(7 \quad$ p). DOI:10.1088/17551315/37/1/012031.

Seavy, N. E.; Viers, J. H.; Wood, J. K.; Eavy, N. A. E. S.; Iers, J. O. H. V. 2009. Riparian bird response to vegetation structure: A multiscale analysis using LiDAR measurements of canopy height. Ecological Applications, 19, 1848-1857.

Stereńczak, K.; Będkowski, K.; Weinacker, H. 2008. Accuracy of crown segmentation and estimation of selected trees and forest stand parameters in order to resolution of used DSM and nDSM models generated from dense small footprint LIDAR data. ISPRS Congress, Beijing, China, Commission VI, WG VI/5, 27-32.

Simard, M.; Pinto; N.; Fisher J. B.; Baccini, A. 2011. Mapping forest canopy height globally with spaceborne LiDAR. Journal of Geophysical Research, 116, G04021. DOI: 10.1029/2011JG001708.

Singh, G. 2008. Sustainable development of peatland for oil palm - UPB "s experience. International Symposium and Workshop on Tropical Peatland: Wise Use and Impact Management. Kuching, Sarawak. 
Stereńczak, K.; Zasada, M. 2011. Accuracy of tree height estimation based on LIDAR data analysis. Folia Forestalia Polonica, Series A 53, (2), 123-129. DOI: 10.5281/zenodo.30859

Su, W.; Liu, R.; Liu, T.; Liu, J. 2012. The Estimation of Tree Height Based on LiDAR Data and QuickBird Imagery. Conference: International Conference on Computer and Computing Technologies in Agriculture. DOI: 10.1007/978-3-642-36137-1_55

Trier, O. D.; Salberg, A. B.; Haarpaintner, J.; Aarsten, D.; Gobakken, T.; Næsset, E. 2018. Multi-sensor forest vegetation height mapping methods for Tanzania, European
Journal of Remote Sensing, 51, 1, 587-606, DOI: 10.1080/22797254.2018.1461533

Van Den Eelaart, A. 2008. Swamp development in Indonesia. Integrated Swamp Development Project (ISDP), IBRD Loan 3755-IND, Indonesia.

Vanicek, P.; Krakiwsky, E. 1986. Geodesy: the concepts. North-Holland, Amsterdam, NY, Oxford, Tokyo.

Zhou, Y.; Hong, W.; Cao, F. 2009. An Improvement of vegetation height estimation using multi-baseline polarimetric interferometric SAR Data. PIERS Online 5, 6-10. DOI: 10.2529/PIERS080907033305. 